\title{
Gratitude Letter: An Effort to Increase Subjective Well-Being in College
}

\author{
Stefanus Arista Christanto, Dea Brenda, Clara Assisiansi, Maria Jessica Pangestu, \\ Ignatia Sarita, and Vania Sulistiani \\ Universitas Kristen Maranatha
}

\begin{abstract}
A preliminary study of students of a psychology faculty, revealed the fact that there are some students with low life satisfaction and negative affect during their college life. Low subjective well-being (SWB) was associated with decreased productivity and cognitive flexibility, which are important elements for studying. Previous researchers found a significant correlation between gratitude and SWB. The aim of this study is to enhance student SWB through an intervention of gratitude letter. We use two stages in this study: first a descript-ive method $(N=282)$ to have an accurate description of the level of their SWB. Then, we select 60 students with the lowest SWB to participate in the next stage, a quasi-experimen-tal method with multiple group design, consisting of two experimental group and one con-trol group. Measurements were conducted with modified SLS, SPANE, and GQ6. Data a-nalysis revealed significant differences in gratitude and positive affect level that are differ-rent in each group. Significant improvement in gratitude and subjective well-being based on the pre-test, post-test 1, post-test 2 were only found in the group that writes and expresses the gratitude letter.
\end{abstract}

Keywords: gratitude letter, gratitude, subjective well-being, college life

Survei awal pada mahasiswa suatu fakultas psikologi menemukan adanya mahasiswa yang kurang memiliki kepuasan dalam hidup, sekaligus merasakan berbagai afek negatif dalam perkuliahan. Kesejahteraan subjektif/subjective well-being (SWB) yang rendah diasosiasikan dengan menurunnya produktivitas dan fleksibilitas kognitif yang merupakan unsurunsur penting dalam perkuliahan. Penelitian-penelitian sebelumnya menemukan adanya hubungan yang signifikan antara rasa syukur (gratitude) dan SWB. Studi ini bertujuan meningkatkan SWB mahasiswa melalui intervensi gratitude letter (GL). Studi ini terdiri atas dua tahap; tahap pertama menggunakan metode deskriptif untuk merekam tingkat SWB mahasiswa. Berdasarkan tahap I kemudian dipilih 60 orang mahasiswa dengan tingkat SWB paling rendah untuk melanjutkan tahap studi kedua, yang menggunakan metode qua-si-experimental dengan multiple group design. Pengukuran dilakukan dengan alat ukur SLS, SPANE, dan GQ6 yang telah dimodifikasi. Analisis data menunjukkan adanya penga-ruh intervensi GL terhadap tingkat SWB mahasiswa berdasarkan beda signifikan (SPANE P, $\eta^{2}=0.095$; GQ-6, $\eta^{2}=0.117$ ) dalam derajat rasa syukur dan emosi positif antar-kelom-pok penelitian. Perubahan yang signifikan pada rasa syukur dan semua aspek SWB berda-sarkan hasil pre-test, post-test 1, dan post-test 2 hanya ditemukan pada kelompok yang me-nulis dan mengekspresikan GL pada orang yang bersangkutan.

Kata kunci: surat syukur, bersyukur, kesejahteraan subjektif, perkuliahan

To achieve some degree of happiness is an essential goal for everyone (Sin \& Lyubomirsky, 2009). Various persons define happiness as a high quality of life, a successful self-actualization, and an adequate

Correspondence concerning this article should be addressed to Stefanus Arista C, Faculty of Psychology, Maranatha Christian University Jalan Prof.drg.Surya Sumantri No. 65 Bandung 40164. Email: stefanus_arista@hotmail.com life. From the traditional concept of positive psychology, happiness is a combination of hedonic happiness and eudemonic well-being (Seligman \& Czikenmihalyi, as cited in Hefferron \& Boniwell, 2011). Hedonic happiness covers a state in which someone is having a high level of positive emotion, a deep negative emotion, and satisfied with life (Diener, Suh, Lucas, \& Smith, 1999). Diener et al. 
named this concept as ability to socialize during subjective well-being (SWB). SWB is defined as a person's belief that he/she has a good, desired, and content life. Individuals who have high SWB tend to show higher level of creativity, increased task persistent, multitasking, systematic, optimism, as well as dealing with negative information related to: longevity, disease resistance, sociability, trust, altruism, and less likely to make enemy, also less egoistic (De Neve, Diener, Tay, \& Xuereb, 2013; Diener \& Biswas-Diener, 2011). SWB has two components: cognitive and affective components. The cognitive component is referred to Diener and colleagues' description in which life satisfaction will be scored based on the discrepancy between one's expectation of an ideal life and their current condition. The affective component of SWB builds on the association of emotion with current experiences (Diener et al., 1999).

Based on the newest study from Gallup et al. (as cited in Hefferon \& Boniwell, 2011), there are five essential elements of well-being: career well-being, social well-being, financial well-being, physical wellbeing, and community well-being. Career wellbeing itself is defined as a state when an individual spends most of their time within a day.

One level of education that can be taken by individuals is a bachelor (S1) and individuals who take the undergraduate level in a university are called a students. Students, in this case, spend most of their daily life in the university parallel with their studies, so the university environment is essential for students' well-being. Related to the situation, we surveyed 61 students from the Faculty of Psychology of University " $\mathrm{X}$ " Bandung by using open-ended question which refers to the aspects of SWB.

Table 1 reveals that college students felt dissatisfaction during their college time even though there were things that already could satisfy them. Other than that, there were negative effects that can influence students' SWB. This matter became a concern for the authors to be able to increase students' satisfaction as well as to increase positive affect in students as an effort to make students gain better SWB in college and get the benefit of better SWB. The contented individual will be able to function more optimally in their life (Sin \& Lyubomirsky, 2009). Furthermore, better happiness also associated positively with better health, optimal career path, and also with better social relation (Pressman \& Cohen, as cited in Sin \& Lyubomirsky, 2009). In the college context, optimizing the learning results and the ability to socialize during college time shall benefit students.

Subjective well-being primarily positive emotions have a relationship with gratitude (Emmons \& McCullough, 2003). Gratitude can help improve subjective well-being by enhancing one's experience of positive events, increasing coping of unfortunate events, and extending social networks from individuals (Emmons \& McCullough, 2003; Rash, Matsuba, \& Prkachin, 2011). Gratitude is also considered to have an essential role as a potential agent to change the level of happiness and subjective well-being by expressing the gratitude itself (Toepfer, Cichy, \& Peters, 2012). McCullough \& Crumpler's research (as cited in Lopez \& Snyder, 2011) shows that practicing gratitude makes individuals feel better about their lives, more optimistic about their life issues and more anticipated or better able to anticipate the negative emotions that may arise when facing various problems. It relates to subjective wellbeing, especially in cognitive evaluation of quality of life and also the appearance of affects both positive and negative.

Open-ended survey results about students' level of gratitude showed that 21 students were often grateful, 23 students were sometimes grateful, while ten students were rarely grateful, and eight students never gave thanks in their daily college life.

Table 2 showed that the way students gave thanks and also complaints in their daily life. College students who rarely gave thanks were found to be complaining a lot and less likely to recognize people who helped them during college. With this phenomenon, namely there were students with a not optimal level of SWB and gratitude, the author intended to increase SWB by increasing their gratitude.

Gratitude itself could be defined as a state in which an individual admits that he or she is receiving good gifts or luck or good things, acknowledging the value of the good things he/she received, and appreciating the good will of the giver (Emmons, 2007). Emmons and McCullough (2003) stated that gratitude consists of recognition toward the fortune that he/she received and acknowledgment or appreciation as a form of identification toward someone, an event, or a thing that he/she perceived as the source of gratitude. A person who feels gratitude recognize that the advantage or gifts he/she had; have been given freely without having to try more to get it (Emmons \& McCullough, 2004). Robert Emmons (as cited in Toepfer, Cichy, \& Peters, 2012) stated 
Table 1

A Preliminary Survey of 61 College Students Based on Each SWB Domains

\begin{tabular}{clr}
$\begin{array}{l}\text { Frequency } \\
\text { (Students) }\end{array}$ & \multicolumn{1}{c}{ Survey's Content } & Domains of SWB \\
\hline 21 & $\begin{array}{l}\text { College students feel that they have achieved expectations in various aspects } \\
\text { of college life such as GPA, supportive friends, skills and knowledge } \\
\text { enhancement during lectures. } \\
\text { College students said that score and GPA that they achieved had not reached } \\
\text { their hope. }\end{array}$ & Life-Satisfaction \\
College students stated that they had not gained knowledge and skills they \\
expected; they also feel that the instructors have not fulfilled their expectancy. \\
College students said that the demand of the assignment was hard therefore \\
the result was felt as not maximal.
\end{tabular}

Table 2

A Preliminary Survey of 61 College Students Based on Each Gratitude Domains

\begin{tabular}{|c|c|c|}
\hline $\begin{array}{l}\text { Frequency } \\
\text { (Students) }\end{array}$ & Survey's Content & Domains of SWB \\
\hline 28 & Being grateful for good scores and improvements during college time. & Recognition \\
\hline 21 & Complaining about tight scheduled of college activities. & \\
\hline 17 & $\begin{array}{l}\text { Disappointment with unfulfilled expectation toward skills and knowledge } \\
\text { gained. }\end{array}$ & \\
\hline 14 & $\begin{array}{l}\text { Being grateful for people who help them face troubles during college such as } \\
\text { doing a difficult assignment. }\end{array}$ & Acknowledgement \\
\hline 6 & Thank God. & \\
\hline 4 & Being grateful for the lecturers. & \\
\hline 20 & Disappointed with the lecturers & \\
\hline 11 & Disappointed with peer groups that are not by expectation. & \\
\hline
\end{tabular}

that a person with gratitude tends to benefit in physical health (such as stronger immune system, rarely get sick, and have lower blood pressure), psychological well-being (such as having higher positive emotion, more attentive and full of energy, more joyful and comfortable), and social relation (such as become more as a helper, generous and care for $\mathrm{o}-$ thers).

One way or one method that can be done to increase gratitude is with gratitude letter (Huffman et al., as cited in Kaczmarek et al., 2015). Gratitude letter is one form of expression of gratitude by writing gratitude to someone (human) or a state or nature or to God (non-human) which bring goodness to the subject (Emmons \& McCullough, 2003). Gra- titude letter is a thank you letter that requires the author to write specifically about what or who influences one's life (Froh, Kashdan, Ozimkowski, \& Miller, 2009). Gratitude letters provide an opportunity for individuals to see the satisfaction or joy and meaning derived from a relationship. Also, the gratitude letter also helps the individual to consider what good things he/she gets from a relationship.

Gratitude letter is a structured way (both in writing and speaking) in creating a story that produces understanding and meaning, provide definition and a sense of control from a person's emotion and experience, also integrate the individual's memory with self-understanding (Blagoy \& Singer, as cited in Toepfer et al., 2012). This showed that reflecting 
the gratitude memory in the form of an organized format can help to recall those experiences. A positive and insightful writing is associated with many final results, including improved health and relations (The Greater Good Science Center, n.d.). The gratitude letter can be used to pour or deliver messages containing gratitude expressions to someone who may have never received a thank you from the individual concerned. Research by Toepfer and Walker (2009) stated that gratitude letter could contribute to bringing positive changes in life through intentional activity. Intentional activity has a significant impact to maintain happiness than situational event because the intentional activity is assumed to be a strong mediator variable (Lyubomirsky, Sheldon, $\&$ Schkade, 2005). The determination to write a gratitude letter support previous research (Sheldon \& Lyubomirsky, 2006) that found that a person can change into a more positive life. Moreover, Kashdan (as cited in Froh, Kashdan, Ozimkowski, \& Miller, 2009) also stated that self-regulation strategy could promote resilience, creation, as well as maintain a positive mood and intrinsic motivation, and also as tools to reduce negative emotion.

Writing a gratitude letter has a more significant effect on a person's happiness compared to other interventions such as counting blessing or gratitude contemplation (Watkins, Woodward, Stone, \& Kolts, 2003). Writing a gratitude letter has been proven to increase happiness and reduce depression in both adolescents and adults (Froh et al., 2009; Toepfer, Cichy, \& Peters, 2012). Froh et al. (2009) found that compared to students who wrote things happen in a day on a daily journal, students who wrote gratitude letter for five days elevated their level of happiness and were more motivated. Pennebaker and Seagal (as cited in Toepfer et al., 2012) also showed that people who wrote positive words and words with inspiration obtained a positive effect such as elevated happiness. Positive words used in a gratitude letter confirm the existence of positive things in life and remind the writer that people care about them - especially during a person's gloomy and lonely period (The Greater Good Action Science Center, n.d.).

Toepfer and Walker (2009) suggested that gratitude letter can be an intervention to help relatively normal individuals (in this case college students) to improve their SWB. Further, they also recommended gratitude letter for college students with stress as well as with symptoms of depression. According to their research, writing gratitude letter was considered as an appropriate method to increase college students' SWB so that students can follow lecture activities more optimally. According to the research by Rath and Harter (as cited in Hefferon \& Boniwell, 2011) on the elements of well-being and based on aspects of gratitude proposed by Emmons and McCullough (2003) where one needs to know the object of gratitude, the individual shall has many aspects to be thankful for. This makes gratitude letter written by the individual could be associated with many aspects of life that can be grateful. The current study focuses on writing gratitude letter with many things in college life that can be thankful for, in other words, writing a gratitude letter to the person that is perceived as giving positive influence toward college life they are living.

\section{Method}

Current research is divided into two studies. Study 1 aims to reveal the subjective well-being level of the students of the Psychology Faculty of " $X$ " University by conducting a population census. Study 2 aims to reveal the effect of gratitude letter intervention to improve subjective well-being through gratitude. The inclusion criteria for study 1 and 2 were the participants who should be at least in their third semester, with an assumption that the students already gain many experiences so that their college life satisfaction can be evaluated.

\section{Participants of Study 1}

The population was students from year 20132015 of Psychology Faculty in "X" University. The participants were students who are willing to fill in the questionnaire $(N=282)$. The participants consist of 40 males $(14.1 \%)$ and 242 (85.9\%) females. There were 91 students (32.2\%) from year 2013, and 86 students (30.4\%) from year 2014, and 105 students $(37.1 \%)$ from year 2015 .

\section{Participants of Study 2}

Based on the 282 college students who fulfill the questionnaire in Study 1 and who want to participate in Study 2, a quota sampling was done to gain 20 subjects per group based on the lowest SWB level, based on the scores of the life satisfaction, as well as scores of positive and negative emotions. Therefore, 60 college students were select- 
ed for Study 2. There were 22 students (36.7\%) from year 2013, 16 students $(26.6 \%)$ from year 2014, and 22 students (36.7\%) from year 2015 . The sixty students were divided into three groups consisting of one control group and two experimental groups at random which will be explained further in the research procedure.

\section{Instruments}

The measurements in this study were conducted using three questionnaires. The SWB was measured with two scales. They were The Satisfaction with Life Scale (SLS) and Scale of Positive and Negative Affect (SPANE). Then the Gratitude Questionnaire6 (GQ6) to measure gratitude. The authors did validation and reliability studies for those questionnaires using internal construct validity with item-total correlation and the Cronbach's alpha. Validation was using 75 students in Faculty of Psychology of "X" University, class of 2013-2015.

SWB instruments used for Study 1 and 2 whereas gratitude instrument was used only in Study 2. The SLS (Diener, Emmons, Larson, \& Griffin, 1985) consist of five items of life level satisfaction. The SPANE (McCullough, Emmons, \& Tsang, 2010) consisting 12 affective words of perceived emotion. The SLS uses a Likert scale; ranged from 1 to 7 that varies from "strongly disagree" to "strongly agree". The SPANE uses a Likert scale, too; ranged from 1 to 5 that varies between "never" to "always". The SPANE consists of two main components: SPANE$\mathrm{P}$ which measures positive emotions and SPANE-N which measures negative emotions. The SLS has a validity range of $.727-.870$ with a value of $\alpha=.844$. The SPANE has a validity range of $.627-.857$ with the values $\alpha=.783$ and .867 (the analysis is done separately for items that measure negative and positive affects).

The GQ-6 measures the degree of gratitude (Mc Cullough, Emmons, \& Tsang, 2002) consists of six items using Likert scales ranging from 1 to 7 that varies between "strongly disagree" to "strongly agree". The GQ6 has a validity ranged of .551 - .807 with the value of $\alpha=.768$. Therefore, all items on all measuring instruments are declared valid. The SLS, as well as GQ6, were modified by the authors to be adjusted to the lecture setting which aims to avoid the normative answer of the students because looking at various aspects of life to assess the subjective well-being or gratitude.

\section{Gratitude Letter}

Gratitude Letter was the intervention given during Study 2. Based on the guidance of writing gratitude letter from The Greater Good Science Center (n.d.), participants were asked to think of someone who ever gave positive influence in their life which makes him/her feel very grateful - and still alive as well as available to meet, but have never been given the gratitude. Later, participants were asked to write a letter to that person according to these steps:

1) Writing a direct letter;

2) Do not have to think about beautiful or perfect words;

3) Describe precisely what has that person done, why it made the participant grateful of it, and how that person's act has affected participant's life;

4) State what participant would do now in their lives and how often participant remember that person's good deed;

5) Later after writing the letter, the participant was asked to read it to the intended person through a telephone (this step only performed by the experimental group 1).

This study focused on how to increase SWB by elevating gratitude through gratitude letter. By choosing career well-being in the education field, the authors modified in some ways to write a gratitude letter. The participants were asked to think and write a letter to the intended person that have done a good deed to them during their college life.

\section{Procedure}

This study was conducted in two stages of research that is Study 1 followed by Study 2. Study 1 aims to get an accurate picture of student SWB levels. Study 2 is an experimental procedure to see the effect of giving gratitude letter on increasing student's SWB. Study 1 used descriptive analysis as a method to describe the population's characteristics (Kumar, 2014). Study 1 surveyed the population with SLS and SPANE questionnaires to the entire student population of year 2013 to 2015 of Psychology Faculty in X University. Questionnaires were given online and preceded by informed consent to gain consent. The informed consent also served as participants' agreement to participate in the followup study, the Study 2. 
Study 2 was using the true experimental method. The design was multiple independent groups using more than two groups of participants and each group got different treatment conditions (Kumar, 2014; Myers \& Hansen, 2002). Sampling was based on a quota by selecting students who stated their willingness to participate in Study 2 when filling in the informed consent and had a low level of SWB based on the SLS and SPANE scores. The primary hypothesis for Study 2 stated that there is a significant effect of gratitude letter toward students' SWB. Also, it is also hypothesized that there are significant changes of SWB before and after the gratitude letter intervention in the experiment group.

There were three groups in this study: a control group and two experimental groups. The groups were randomly selected using an application from www.random.org. Both control and experimental groups did the pre-test and post-test to compare the effect of gratitude letter treatment. SLS, SPANE, and GQ6 were given as the pre-test and post-test. At first, participants received an informed consent as the agreement to participate in the whole experiments, especially by agreeing to attend the data collection procedure and fulfill the questionnaires. The pretest was given one day before the treatment day, while the first post-test was given one day after the treatment day. The treatment for the first experimental group was involving writing a gratitude letter and reading it to the intended person through a telephone, while the treatment for the second experimental group was only involving writing a gratitude letter without reading it to the intended person. The participants were given unlimited time to complete all tasks during treatment day. The tasks were observed and delivered by a tester. Later on, the second post-test would be done within seven days after the treatment day to measure the long-term effect or the stability of the treatment. The participants in the control group were only asked to fulfill SLS, SPANE, and GQ6 questionnaires during pre-test and post-test without any treatment. This group would be called as the waiting list group because the treatment would be given after the second post-test data collections from the other groups were finished.

\section{Data Analyses}

The analysis in Study 1 was using frequency table with $\mathrm{f} / \mathrm{n} \times 100 \%$ formula (Field, 2013) to determine the category from SLS and SPANE. The ana- lysis in Study 2 used mixed factor ANOVA that merged the variables of between group and repeated measure; 3 (group) x 3 (pre- and post-test results). There would be three scores to compare: the pretest, post-test I and post-test II and three groups to compare: control group, experimental group 1, and experimental group 2. The mixed factor measure SLS, SPANE and GQ6 scores. Statistical analysis toward GQ-6 has been done to ensure that changes to SWB score were caused by the increase of gratitude due to gratitude letter treatment. Repeatedmeasures ANOVA was also carried out for each group to examine the variables change within each group. Spherical assumption was checked to ensure between group variance were equal. In this case, if spherical assumption was rejected, the multivariate analysis could be an alternative to analyze the results. Partial eta-squared also calculated to examine the score differences due to the treatment effect.

\section{Results}

\section{Study 1}

The results of Study I indicate that there are variations in the subjective well-being level of the student either from life satisfaction or negative and positive emotions. Table 3 shows the frequency distribution of students' subjective well-being levels viewed based on life satisfaction through SLS measurements as well as emotions consisting of positive emotions based on SPANE-P values and negative emotions based on SPANE-N values.

Results from Study 1 showed that there is a variation of SWB scores from all SWB measurements (Satisfaction with Life Scale, SPANE-P, and SPANE$\mathrm{N})$. Based on the Life Satisfaction score, most students $(81.6 \%)$ showed average life satisfaction. This means that the students have things that have met the ideal they wanted, but also things that have not met to their satisfaction that is showed in their dissatisfaction with many things like GPA, social life, and learning activities that have not fulfilled their ideal expectation.

Based on emotion experienced by the students, most students $(61.4 \%)$ have a high level of positive emotion. However, there are also students with low level of positive emotion (5.7\%). The college students with high level of positive emotion could feel the much positive emotion in college life such as happiness and joy. Meanwhile, based on the negative 


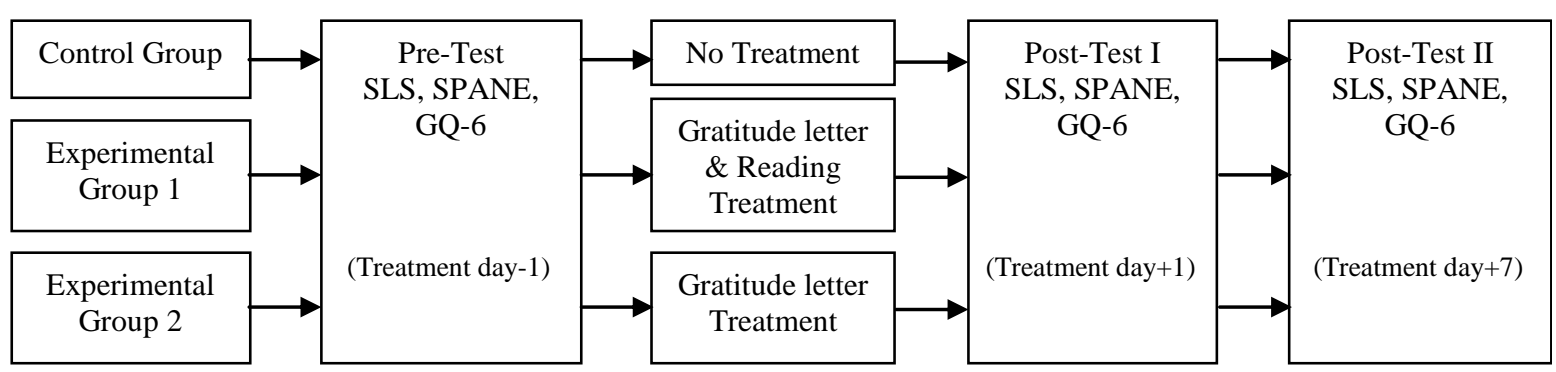

Figure 1. Research procedure chart of Study 2.

Table 3

Frequency Distribution of Subjective Well-Being Based on SLS and SPANE

\begin{tabular}{lcr}
\hline \multicolumn{1}{c}{ Measurement } & $\boldsymbol{n}$ & \% \\
\hline Satisfaction With Life Scale & & .7 \\
Dissatisfied With Life & 2 & 81.6 \\
Neutral Life Satisfaction & 230 & 17.7 \\
Satisfaction With Life & 50 & \\
& & \\
SPANE - P & 18 & 6.4 \\
Low Positive Emotion & 91 & 32.3 \\
Moderate Positive Emotion & 173 & 61.4 \\
High Positive Emotion & & \\
& & \\
SPANE - N & 90 & 31.9 \\
Low Negative Emotion & 129 & 45.7 \\
Moderate Negative Emotion & 63 & 22.3 \\
High Negative Emotion & &
\end{tabular}

emotion score, most students were at a moderate level of negative emotion (45.7\%), and there were students with high level of negative emotion $(22.3 \%)$. The students with negative emotion felt more stressful in living the college life.

Study 1 result showed that students had a high level of SWB because they had high positive emotion and had satisfaction with life. However, there were also students with low SWB because they had moderate and high negative emotion and had average life satisfaction. Sixty students who scored highest on negative emotion score, lowest on positive emotion score and lowest on life satisfaction score were selected from this study to participate in Study 2.

\section{Study 2}

\section{Assumptions Test}

The results of spherical assumption for each questionnaires were $\chi^{2}(2)=41.658, p<.001$ for GQ-6, $\chi^{2}(2)=23.814, p<.001$ for SLS, $\chi^{2}(2)=37.205, p<$
.001 for SPANE-N, $\chi^{2}(2)=26.414, p<.001$ for SPANE-N, and $\chi^{2}(2)=3.333, p=.189$ for SPANE$\mathrm{B}$. These results showed that the spherical assumption for all questionnaires was rejected, except for SPANE-B. Therefore, the multivariate analysis would test the hypothesis that the gratitude letter significantly affects SWB. The result of spherical assumption test toward the supporting hypothesis showed that all assumption for the test groups were fulfilled. Therefore, the analysis would be done by repeated-measure ANOVA.

\section{The Gratitude Letter's Influence on Subjective Well-Being}

Results of Study II revealed significant differences between degree of gratitude $(\lambda(4.116)=0.780$, $p=.006)$ and also positive emotion $(\lambda(4.116)=$ $0.820, p=.020)$ seen based on pre-test, post-test I and post-test II between control group, experimental group 1, and experimental group 2. Based on criteria of effect size partial eta squared Cohen (1995), either positive emotion $(\eta 2=0.095)$ or gratitude $(\eta 2$ $=0.117$ ) medium level. The results of this study found no significant difference for the degree of life satisfaction, negative emotions, or balance (the result of positive emotional reduction with negative emotions).

Emmons and McCullough (2003) stated that gratitude could increase subjective well-being by promoting positive life experiences. Research by Seligman (as cited in Wood, Froh, \& Geraghty, 2010) also showed high positive emotion on participants when they practice gratitude $(d=0.34)$. A person who expresses his gratitude could assist himself to feel a higher level of happiness (Gallup, as cited in Hefferon $\&$ Boniwell, 2011). This is because the positive event or the luck that happen upon a person is interpreted with more meaning that makes the person feel more positive emotion. 
Gratitude as a trait is more associated with how an individual becomes more likely to live a positive event. Meanwhile, gratitude as a state (state gratitude) is a person's positive feeling when that person obtains goodness or positive things. Current results showed that writing a gratitude letter increase state gratitude significantly than not writing a gratitude letter. Table 4 revealed that although the experimental group 1 had lower scores on SPANE-P compared to control group, the post-test I showed that the experimental group 1 had higher level positive emotion. It means that positive emotion was elevated after treatment was given to experimental group 1. When viewed based on the aspects of gratitude, the intentional to write the gratitude letter makes students search for positive events or benefits they received (recognition aspects) and make students recognize other individuals as the benefactor (acknowledgment aspect). The inclination of state gratitude makes the positive emotions felt by students increase. Emotion itself could be affected by internal or external stimuli. Therefore, self (internal) changes could have an impact on a person's emotional state.

Also, gratitude letter expression also raises significant differences in positive emotions and gratitude levels by directly writing letters. Froh et al. (2009) explained being thankful one does not mean that one is expressing a meaningful gratitude. Writing gratitude letter helps a person to express gratitude that already been thought for long so that when the letter is read, it provided more acknowledgment and recognition gratitude than me-rely a (written) letter. That way, the change of state gratitude became higher and resulted in a higher chance of positive emotions.

Table 4 and Table 5 showed that there are significant differences in SLS, SPANE-P, SPANE-N, and GQ-6 primarily from pre-test and post-test I results in experimental group 1 when compared with control group. According to the observation of experimental group 1, all participants were crying while reading the letter. When the participants were asked what they felt when writing or reading the letter, some participants said that they just realized how precious the help they got from that person and some participants stated that they were so happy to be able to say thank you properly to the intended person. In accordance with Seligman, Steen, Park, and Peterson (2005) research, when someone expresses his/her gratitude directly, this act would increase the SWB that is closely related to positive emotions. This is supported with a current effect size of the positive emotion of SWB $\left(\eta^{2}=0.323\right)$. The pair wise comparison of pre-test, post-test I, and post-test II, showed significant changes on SLS $(p=.007)$, SPANE-B $(p<.001)$, and GQ-6 ( $p=$ .041 ) of post-test I but not on the post-test II (SLS $p$ $=1.0$, SPANE-B $p=.420$, GQ-6 $p=1.0$ ). The results indicate that the effect of writing a gratitude letter was not a merely brief effect, but the effect is stable for a week.

There were no significant changes in positive emotions, negative emotions, and life satisfaction on experimental group 2. It was observed that several students showed changes of emotion when writing the letter, such as crying as well as smiling. However, not many students in this group showed the change of emotion compared to the experimental group 1. The changes of emotion (i.e. crying and laughing) was most noticeable during the reading session. There were no emotion changes observed in experimental group 2 because the letter was not read in this group. If a person is only writing the letter without giving it to the intended person, it limited the expression of gratitude. It might also be limiting the cognitive evaluation so that there were no significant changes found on life-satisfaction.

\section{Discussion}

Studies by Seligman, Steen, Park, and Peterson (2005) and Toepfer et al. (2012) were intended to see the effect of gratitude letter on SWB in general and also to reduce depressive symptoms. Gallup et al. (as cited in Hefferon \& Boniwell, 2011) showed that well-being could be categorized into many aspects of life. There is a chance that when a person SWB is high in an area, it is lower in another area. Current results showed that gratitude letter could be a treatment used to increase SWB, specifically to increase college students' career well-being. College students with low SWB could be less optimal in living their college life, especially in learning with cognitive flexibility, productivity, as well as sociallization to promote teamwork required in the group.

In general, positive psychological intervention focuses on how to develop a person toward a better direction by improving the positive characters within that person. SWB improvement, especially with positive emotion improvement, was expected to make students happier and feel less depressed in college life. This intervention could make the stu- 
Table 4

Hypothesis Testing Using Mixed-Factor 3x3 and Test Repeated Measures of Each Group

\begin{tabular}{lccccr}
\hline Statistical Test & SLS & SPANE-N & SPANE-P & SPANE-B & GQ-6 \\
\hline $\begin{array}{l}\text { Multivariate Analysis (Wilks- } \\
\text { Lambda) }\end{array}$ & 0.925 & 0.908 & $0.820^{*}$ & 0.870 & $0.780^{*}$ \\
$\begin{array}{l}\text { Repeated Measures ANOVA } \\
\text { Control Group F(2.38) }\end{array}$ & 1.807 & 1.404 & 0.017 & 0.619 & 3.211 \\
$\begin{array}{l}\text { Repeated Measure ANOVA } \\
\text { Experimental Group 1 F(2,38) }\end{array}$ & $\begin{array}{c}7.863^{* *} \\
\eta^{2}=0.282\end{array}$ & $\begin{array}{c}5.507^{*} \\
\eta^{2}=0.208\end{array}$ & $\begin{array}{c}10.012^{* *} \\
\eta^{2}=0.323\end{array}$ & $\begin{array}{l}10.247^{* *} \\
\eta^{2}=0.328\end{array}$ & $\eta^{2}=0.149$ \\
$\begin{array}{l}\text { Repeated Measure ANOVA } \\
\text { Experimental Group 2 F(2,38) }\end{array}$ & 0.642 & 1.929 & 1.462 & 0.704 & 1.364 \\
$\begin{array}{l}\text { Repeated Measure ANOVA } \\
\text { Control Group F(2.38) }\end{array}$ & 1.807 & 0.271 & 0.017 & 0.619 & 3.211 \\
\hline $\begin{array}{l}\text { Note. }{ }^{*} p<.05,{ }^{*} p<.01 \\
\end{array}$ & & & & &
\end{tabular}

Table 5

Mean and Standard Deviation Pre-Test, Post-Test I, and Post-Test II on SLS, SPANE, and GQ on Control Group, Experimental Group 1, and Experimental Group

\begin{tabular}{lcccccr}
\hline Group & \multicolumn{2}{c}{ Pre-Test } & \multicolumn{2}{c}{ Post-Test I } & \multicolumn{2}{c}{ Post-Test II } \\
\cline { 2 - 7 } & $\boldsymbol{M}$ & SD & $\boldsymbol{M}$ & $\boldsymbol{S D}$ & $\boldsymbol{M}$ & SD \\
\hline Control Group & & & & & & \\
SLS & 20.90 & 4.447 & 21.90 & 4.599 & 22.05 & 4.559 \\
SPANE-P & 20.10 & 3.243 & 20.00 & 2.991 & 20.10 & 3.768 \\
SPANE-N & 18.60 & 3.202 & 17.50 & 3.576 & 17.75 & 2.936 \\
GQ-6 & 30.30 & 3.450 & 29.25 & 3.919 & 28.55 & 4.651 \\
& & & & & & \\
Experimental Group 1 & & & & & & \\
SLS & 19.10 & 2.548 & 21.33 & 2.921 & 21.29 & 3.466 \\
SPANE-P & 18.41 & 3.276 & 20.36 & 2.787 & 20.45 & 3.488 \\
SPANE-N & 19.23 & 3.294 & 17.55 & 3.515 & 18.27 & 3.210 \\
GQ-6 & 28.05 & 3.685 & 30.18 & 3.936 & 29.73 & 4.211 \\
& & & & & & \\
Experimental Group 2 & & & & & & \\
SLS & 21.85 & 3.760 & 22.55 & 3.748 & 20.80 & 8.192 \\
SPANE-P & 20.10 & 3.538 & 20.80 & 2.931 & 18.50 & 6.817 \\
SPANE-N & 19.40 & 3.378 & 19.10 & 3.417 & 17.35 & 6.675 \\
GQ-6 & 30.60 & 2.945 & 30.25 & 3.810 & 27.60 & 10.210 \\
\hline
\end{tabular}

dents enjoying more lectures and other activities in college as well as socialization within circles of friends so that students could achieve optimal learning outcome. The college students could write gratitude letter by writing a letter to the intended individuals who were considered to give positive influence to their college life but have not got the chance to thank them properly. Writing gratitude letter was expected to provide a new perspective on students who got negative experiences in college, that there are also experienced positive events or things in the- ir college life. The students who are being thankful for positive things in their life were expected to feel a positive emotion and to have a more positive cognitive evaluation (of themselves). SLS, SPANE, and GQ-6 showed a declining trend; life satisfaction and gratitude tend to decline. Moreover, it also showed rebound of negative emotion (it also showed elevation on negative emotion). Although it was not significant, these results revealed that students have to practice writing gratitude letter periodically because the gratitude letter has only had a situational or 
temporary effect. Research conducted by Rash et al. (2011) and Toepfer et al. (2012) showed an everincreasing change when the gratitude letter is practiced once a week.

\section{Research Limitations and Suggestions}

There are some limitations in current study. The first limitation related to the rejection of the spherical assumption in mixed factor ANOVA data analysis. The rejection indicated there were different varians between the groups. There was a big differrent standard deviation on the experimental group II during post-test II that had standard deviation variation that varies almost three times in GQ, SPANE-P, SPANE-N, and SLS, so that spherical correction was difficult to equate the data variation. In this case, the researcher used an alternative multivariate tests analysis to determine if the hypothesis should be rejected or accepted.

The current study emphasizes more on how temporary change of gratitude as a state could affect students' level of SWB. The authors would like to suggest to examine the longitudinal effect of gratitude as well as to exam if there would be permanent changes or gratitude trait changes. Further, a study on the effect of better SWB affects students' life. Future research could add treatments to examine the longitudinal effect as well as to examine if SWB improvement could occur permanently. Duration, social support, and treatment variations into things that need to be considered in the provision of positive psychological treatment to be able to bring a significant effect (Lyubomirsky \& Layous, 2013). Future researchers also need to consider the sample size; noted that the limitation of the current study is that the spherical assumption was rejected. Current results also indicated that further research on interventions to increase SWB in the context of college students is needed. It is required because the author has not found any research on similar or different treatments that could be a comparison to the current study. Further research also needed to establish the "golden standard' of treatment effectiveness to increase the SWB of students' with low SWB to maximize students' college activity.

\section{Conclusion}

Based on this study, gratitude letter can be a form of intervention that could be applied to improve the subjective well-being of students so that students can be more optimal in following university activities either academically or socially.

\section{References}

Cohen, J. (1995). Statistical power analysis for the behavioral sciences. Hillsdale, NJ: Erlbaum.

De Neve, J.-E., Diener, E., Tay, L., \& Xuereb, C. (2013). The objective benefits of subjective wellbeing. In J. Helliwell, R. Layard, \& J. Sachs (Eds.), World Happiness Report 2013. New York: UN Sustainable Development Solutions Network.

Diener, E., \& Biswas-Diener, R. (2011). Happiness: Unlocking the mysteries of psychological wealth. Malden (Massachusetts): Blackwell.

Diener, E., Emmons, R. A., Larson, R. J., \& Griffin, S. (1985). The satisfaction with life scale. Journal of Personality Assessment, 49, 71-75.

Diener, E., Suh, E. M., Lucas, R. E., \& Smith, H. L. (1999). Subjective well-being: Three decades of progress. Psychological Bulletin, 125(2), 276-302.

Emmons, R. A., \& McCullough, M. E. (2004). The psychology of gratitude. Oxford: Oxford University Press.

Emmons, R. A. (2007). Thanks!: How the new science of gratitude can make you happier. Boston: Houghton Mifflin Co.

Emmons, R. A., \& McCullough, M. E. (2003). Counting blessings versus burdens: An experimental investigation of gratitude and subjective well-being in daily life. Journal of Personality \& Social Psychology, 84(2), 377-389.

Field, A. (2013). Discovering statistics using IBM statistics (4th ed.) London: Sage Publications Ltd.

Froh, J. J., Kashdan, T. B., Ozimkowski, K. M., \& Miller, N. (2009). Who benefits the most from a gratitude intervention in children and adolescents? Examining positive affect as a moderator. The Journal of Positive Psychology, 4(5), 408-422.

Hefferon, K., \& Boniwell, I. (2011). Positive psychology: Theory, research, application. New York: McGraw-Hills.

Kaczmarek, L. D., Kashdan, T. B., Drążkowski, D., Enko, J., Kosakowski, M., Szäefer, A., \& Bujacz, A. (2015). Why do people prefer gratitude journaling over gratitude letters? The influence of individual differences in motivation and personality on web-based interventions. Personality and Individual Differences, 75, 1-6.

Kumar, R. (2014). Research methodology: A stepby-step guide for beginners. London: SAGE. 
Lopez, S. J., \& Snyder, C. R. (2011). Handbook of positive psychology. Oxford: Oxford Univ. Press.

Lyubomirsky, S., \& Layous, K. (2013). How do simple positive activities increase well-being? Current Directions in Psychological Science, 22(1), 57-62.

Lyubomirsky, S., Sheldon, K. M., \& Schkade, D. (2005). Pursuing happiness: The architecture of sustainable change. Review of General Psychology, 9(2), 111-131.

McCullough, M. E., Emmons, R. A., \& Tsang, J. (2002). The grateful disposition: A conceptual and empirical topography. Journal of Personality and Social Psychology, 82, 112-127.

Myers, A., \& Hansen, C. H. (2002). Experimental psychology. Pacific Grove, CA: Wadsworth/Thomson Learning.

Rash, J. A., Matsuba, M. K., \& Prkachin, K. M. (2011). Gratitude and well-being: Who benefits the most from a gratitude intervention? Applied Psychology: Health and Well-Being, 3(3), 350-369.

Seligman, M. E., Steen, T. A., Park, N., \& Peterson, C. (2005). Positive psychology progress: Empirical validation of interventions. American Psychologist, 60(5), 410-421.

Sheldon, K. M., \& Lyubomirsky, S. (2006). Achieving sustainable gains in happiness: Change your actions, not your circumstances. Journal of Happiness Studies, 7(1), 55-86.

Sin, N. L., \& Lyubomirsky, S. (2009). Enhancing wellbeing and alleviating depressive symptoms with positive psychology interventions: A practice-friendly meta-analysis. Journal of Clinical Psychology, 65(5), 467-487.

The Greater Good Science Center. (n.d.). Gratitude letter. Retrieved from http://ggia.berkeley.edu/pr actice/gratitude_letter

Toepfer, S. M., Cichy, K., \& Peters, P. (2012). Letters of gratitude: Further evidence for author benefits. Journal of Happiness Studies, 13(1), 187-201.

Toepfer, S., \& Walker, K. (2009). Letters of gratitude: Improving well-being through expressive writing. Journal of Writing Research, 1(3), 181-198.

Wood, A. M., Froh, J. J., \& Geraghty, A. W. (2010). Gratitude and well-being: A review and theoretical integration. Clinical Psychology Review, 30(7), 890-905.

Watkins, P. C., Woodward, K., Stone, T., \& Kolts, R. K. (2003). Gratitude and happiness: Development of a measure of gratitude, and relationships with subjective well-being. Social Behavior and Personality, 31(5), 431-452. 